\title{
The validity of rapid test to detect prostate-specific antigen (PSA) in seminal fluid
}

\author{
Henky, ${ }^{1}$ Yuli Budiningsih, ${ }^{2}$ Wibisana Widiatmaka ${ }^{2}$ \\ ${ }^{1}$ Department of Forensic Medicine, Faculty of Medicine Universitas Udayana, Bali, Indonesia \\ ${ }^{2}$ Department of Forensic Medicine and Medicolegal, Faculty of Medicine Universitas Indonesia, Jakarta, Indonesia
}

\begin{abstract}
Abstrak
Latar belakang: Penelitian ini membahas tentang penggunaan alat uji cepat (rapid test device) untuk mendeteksi ProstateSpecific Antigen (PSA) dalam cairan mani secara spesifik, sebagai upaya pengungkapan kasus kejahatan seksual.

Metode: Penelitian ini merupakan penelitian potong lintang analitik. Sebanyak 45 sampel cairan mani dan urin diambil secara consecutive. Cairan mani diencerkan secara bertingkat hingga 1:5.000.000 dan urin laki-laki hingga 1:200 menggunakan akuades, sedangkan urin perempuan tidak diencerkan. Pemeriksaan dilakukan dengan menggunakan rapid test PSA.
\end{abstract}

Hasil: Proporsi hasil pemeriksaan PSA yang positif pada cairan mani, urin laki-laki, dan urin perempuan berturutturut $100 \%, 6,67 \%$, dan $0 \%$. Secara statistik perbedaan proporsi ini sangat bermakna. Nilai diagnostik rapid test device PSA untuk mendeteksi cairan mani adalah sensitivitas 100\%, spesifisitas 96,67\%, NDP 93,75\%, NDN 100\%, RKP 33,33, RKN 0, dan AUC 0,983.

Kesimpulan: Rapid test PSA sangat spesifik dan sensitif untuk mendeteksi PSA dalam cairan mani. Oleh karena itu, praktisi forensik disarankan untuk menggunakan alat ini untuk mengungkap kasus kejahatan seksual. (Med J Indones 2011; 20:278-82)

\begin{abstract}
Background: This study was conducted to determine whether the rapid test device can be used to detect PSA in seminal fluid specifically, for solving sexual assault cases.

Methods: A cross sectional study has been conducted. A total of 45 samples were taken consecutively. Semen was diluted in serially up to 1:5.000.000 and male urin up to 1:200 using distilled water, whereas female urin was not diluted. Samples were analyzed using rapid test PSA.

Results: The proportion of positive results of PSA in seminal fluid, male urin and female urin respectively was $100 \%$, $6.67 \%$, and $0 \%$. Statistically, these differences are highly significant. The analysis revealed that the PSA rapid test device was $100 \%$ sensitive and $96.67 \%$ specific to detect seminal fluid. The test also have PPV $93.75 \%$, NPV $100 \%$, LR(+) 33.33, LR(-) 0, and AUC 0.983.

Conclusion: PSA Rapid Test is very specific and sensitive to detect PSA in seminal fluid. Therefore, this device is suggested for forensic use in sexual assault cases. (Med J Indones 2011; 20:278-82)
\end{abstract}

Key words: $P S A$, rapid test, sexual assault

Globally, the incidence of sexual assault cases, especially rape, is increasing. Findings from the National Violence Against Women Survey (NVAWS) in 1995-1996, a survey of 8000 women, reported $17.6 \%$ (1 of every 6 ) of surveyed women had been raped at some time in their lives. ${ }^{1-3}$ In United States, about 75000 rape cases happened every year. ${ }^{1,4,5}$ Statistics from the United Nations Survey of Crime Trends and Operations of Criminal Justice Systems showed the prevalence of rape in Indonesia is 0.57 every 100000 people. $^{6}$

Ironically, there are many unsolved cases due to lack of evidence. ${ }^{2,7}$ The role of forensic doctor in revealing the rape cases is to prove any signs of sexual intercourse, by collecting evidence of penetration and ejaculation. ${ }^{8}$

The evidence of ejaculation can be proven by specific component from the seminal fluid, whether it is a cellular or plasma component. The cellular component that routinely examined is spermatozoa, whereas the plasma components are crystal choline and spermine, acid phosphatase, and zinc. Nowadays, these examinations are no longer being used since they are unspecific and impractical. $^{9-4}$

A Component considered the most specific for seminal fluid is Prostate-Specific Antigen (PSA). Graves ${ }^{14}$ confirming that PSA is very specific for seminal fluid. Thus, if PSA is found in vaginal fluid, it will ensure the sexual intercourse. ${ }^{15}$

Although PSA was thought to be prostate-specific, reports of its identification in extra-prostatic tissue has been published. Several researchers showed that PSA is steroid-dependent, and it can be detected in various tissues and body fluids, including in females. ${ }^{16}$ Urin, both derived from male and female, contained PSA in high concentration compared to other body fluids. The finding 
of urin on a pair of underwear from a rape survivor would not be uncommon. However, PSA concentration in urin is thousand fold lower than seminal fluid..$^{17,18}$

The examination of PSA in seminal fluid quantitatively is difficult and quite expensive, so it was never done in Indonesia. Fortunately, there is a rapid test for checking PSA, which is very practical, quick, easy to use, inexpensive, and quite sensitive and spesific. However, this rapid test is designed to check the PSA concentration in blood, plasma, and serum. Thus, this study was conducted to determine whether the PSA rapid test could be used to detect PSA in seminal fluid specifically.

\section{METHODS}

This is a cross-sectional study, conducted at the Department of Forensic Medicine, Biology, MAKMAL, and Clinical Laboratory Faculty of Medicine University of Indonesia in April 2011. Fresh seminal fluid and male urin samples were taken from 30 men arranged to visit the Department of Biology and MAKMAL, while the female urin samples were taken from 15 women to Clinical Laboratory. Subjects were chosen consecutively. This study was conducted in two steps.

Preliminary phase was conducted to find out the optimal seminal fluid dilution. Five samples of seminal fluid were diluted serially to the level of $4 \mathrm{ng} / \mathrm{ml}$ according to cut off point of the rapid test. By using the test tube, samples were diluted with distilled water up to 1 in 5 million ppm.

Then, two drops of samples were transferred to the test device. After a 5-minute incubation at room temperature to allow sample migration throughout the test strip, a positive result was indicated by the appearance of a pink line in the test, the reference, and the control area. A negative result was indicated by a line in the reference and the control area only. Tests without a visible pink reference and/or control line were considered invalid. Furthermore, the positive result were grouped into classifications based on the degree of positiveness: weak positive, positive, strong positive, and very strong positive. A test is interpreted as weak positive, if the color intensity that formed in the test area is more vague than the reference area. A test is interpreted as positive, if the color intensity that formed in the test area is equal with the reference area. A test is interpreted as strong positive, if the color intensity that formed in the test area is more visible than the reference area. A test is interpreted as very strong positive, if the color intensity that formed in the test area is the most tangible.

The next step was to compare 15 most optimal dilution samples of seminal fluid with 15 samples of male urin which was diluted up to 1 in 200 , and with 15 samples of undiluted female urin. The proportion of positive result in seminal fluid and urin was calculated and then comparatively analyzed using chi square. Then, to find out sensitivity \& specificity of $A C O N^{\circledR} P S A$ SemiQuantitative Rapid Test Device (ACON Laboratories, San Diego, $C A$ ) diagnostic test analysis was done with body fluid (semen or non semen) as a gold standard.

\section{RESULTS}

Mean age of male subjects was 32 years old and all of them were married. $6,7 \%$ of the seminal fluid was azoospermia, $40 \%$ was oligospermia, and 53,3\% normospermia. Mean age of female subjects was 37 years old, and $66,7 \%$ were married. Details of subject characteristics are shown in table 1.

Table 1. Subject Characteristics

\begin{tabular}{lc}
\hline Male (N=30) & \\
\hline Married & $30(100 \%)$ \\
Age (years) & $32(21-56)$ \\
Sexually active & $30(100 \%)$ \\
Wet dreams (years) & $13(10-16)$ \\
Abstinence (days) & $4(3-9)$ \\
Seminal fluid volume (ml) & $3,13(0,5-5)$ \\
Sperms count (N=15) & \\
$\quad$ Normospermia & $8(53,3 \%)$ \\
Oligospremia & $6(40,0 \%)$ \\
Azoospermia & $1(6,7 \%)$ \\
Urin volume (ml) & $19,83(12-24)$ \\
\hline Female (N=15) & \\
\hline Married & $10(66,7 \%)$ \\
Age (years) & $37(21-69)$ \\
Sexually active & $8(53,3 \%)$ \\
Menarche (years) & $14(12-17)$ \\
Last menstrual period (days) & $10(5-16)$ \\
Abstinence (days) & $25(3-60)$ \\
Leukorea & $5(33,3 \%)$ \\
Urin Volume (ml) & $23,77(15-33)$ \\
& \\
\hline
\end{tabular}

Figure 1 shown percentage of PSA reactivity in various dilution of seminal fluid. All of undiluted seminal fluid showed negative results and all of the samples showed positive results at $1: 100$. The optimal level of seminal fluid dilution is $1: 5.000$, since all tests gave very strong positive results at this level.

The proportion of positive results of PSA in seminal fluid, male urin and female urin are shown in table 2 and 3 , which respectively are $100 \%, 6.67 \%$, and $0 \%$. This difference is statistically highly significant $(\mathrm{p}=0,000)$.

The diagnostic value of PSA rapid test to detect seminal fluid are sensitivity $100 \%$, specificity $96,67 \%$, PPV 93,75\%, NPV 100\%, LR (+) 33,33, LR(-) 0, and AUC 0,983 as shown in table 4 . 


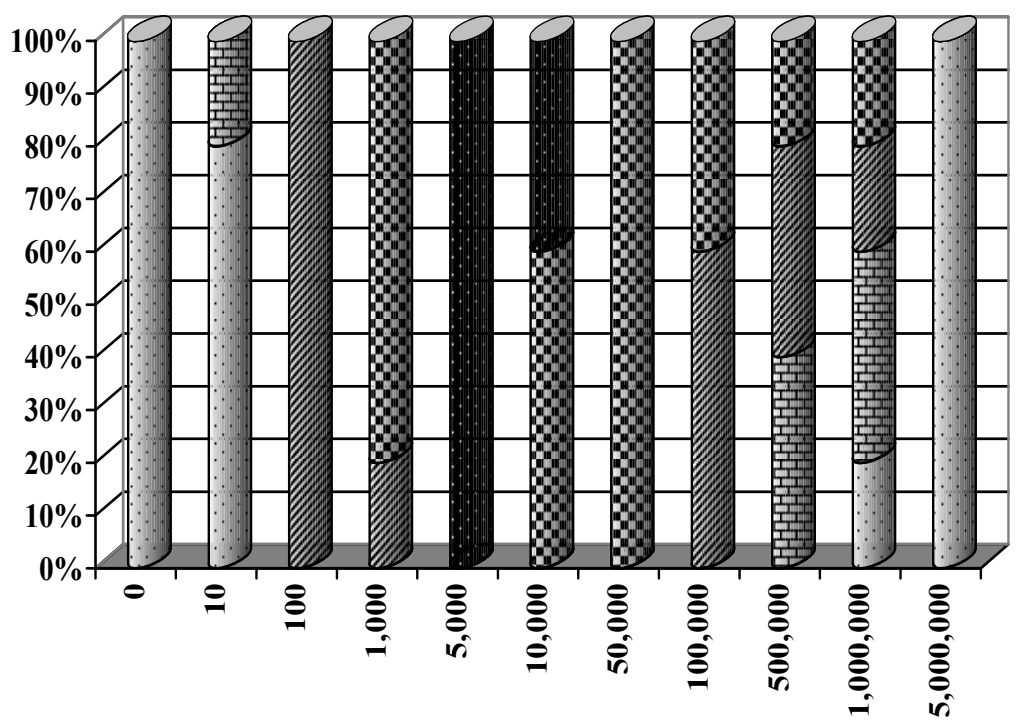

Figure 1. Percentage of PSA reactivity in various dilution of seminal fluid using rapid test

Legends:

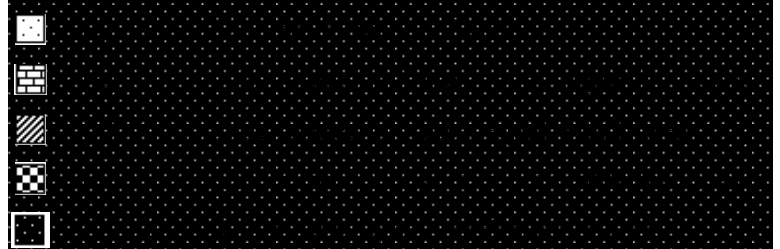

Table 2. The proportional difference of PSA reactivity in seminal fluid and male urin

\begin{tabular}{lccc}
\hline & PSA (+) & PSA (-) & Total \\
\hline Seminal fluid (1/5.000 dilutions) & $15(100 \%)$ & 0 & $15(100 \%)$ \\
Male urin (1/200 dilutions) & $1(6,67 \%)$ & $14(93,33 \%)$ & $15(100 \%)$ \\
& 16 & 14 & 30 \\
\hline
\end{tabular}

$x^{2}=26,25 ; d f=1 ; p=0,000$

Table 3. The proportional difference of PSA reactivity in seminal fluid and female urin

\begin{tabular}{lccc}
\hline & PSA $(+)$ & PSA (-) & Total \\
\hline Seminal fluid (1/5.000 dilutions) & $15(100 \%)$ & 0 & $15(100 \%)$ \\
Female urin (without dilutions) & 0 & $15(100 \%)$ & $15(100 \%)$ \\
& 15 & 15 & 30 \\
\hline
\end{tabular}

$\mathrm{x}^{2}=30,00 ; \mathrm{df}=1 ; \mathrm{p}=0,000$

Table 4. The validity of PSA rapid test to detect seminal fluid

\begin{tabular}{clcc}
\hline & \multicolumn{1}{c}{$\begin{array}{c}\text { Seminal Fluid } \\
1 / 5.000 \text { Dilutions }\end{array}$} & $\begin{array}{c}\text { Non } \\
\text { Seminal Fluid }\end{array}$ \\
\hline PSA (+) & \multicolumn{1}{c}{15} & & 1 \\
PSA (-) & \multicolumn{1}{c}{0} & & 29 \\
\hline Sensitivity & $=100 \%$ & LR $(+)$ & $=33,33$ \\
Specificity & $=96,67 \%$ & LR(-) & $=0$ \\
PPV & $=93,75 \%$ & AUC & $=0,983$ \\
NPV & $=100 \%$ & & \\
\hline
\end{tabular}

$\mathrm{x}^{2}=40,78 ; \mathrm{df}=1 ; \mathrm{p}=0,000$

\section{DISCUSSION}

Seven percent of the seminal fluid was azoospermia, but all seminal fluid tested by PSA rapid test showed positive results. This result support the theory saying; if spermatozoa was not found, we were still unable to conclude that the specimen was not seminal fluid because the seminal fluid consists of two component: spermatozoa and plasma (including PSA). ${ }^{9-14}$

All of undiluted seminal fluid showed negative results. This condition is called "high-dose hook effect" which happens due to the excessive amount of free PSA. The PSA rapid test is designed to detect PSA in low concentrations. Therefore, if seminal fluid is directly tested on this device, it will cause a false negative result, because the PSA level in seminal fluid is very high $\left(0,2-5,5 \times 10^{6} \mathrm{ng} / \mathrm{ml}\right)$. This excessive amount of free PSA will interfere the formation of antigen-antibody complex. ${ }^{19-21}$

At $1: 100$ dilutions, all of the samples showed positive results. This finding is in accordance with a threshold of PSA concentration that does not cause the "high-dose hook effect" in the rapid test that has been used. It is about $30.000 \mathrm{ng} / \mathrm{ml} .{ }^{19}$ Hochmeister ${ }^{18}$ also recommends to dilute seminal fluid at least 1 in 100 to avoid "highdose hook effect".

When diluted up to 5 million, all seminal fluid showed negative results. This finding is somewhat different from the 
study by Laux ${ }^{22}$ which showed negative results at dilution level above five hundred thousand, Hochmeinster ${ }^{18}$ at the level above one million and three hundred thousand, and Sato $^{21}$ above two million. This difference may be caused by the variation of PSA concentration in seminal fluid among subjects, the difference of the rapid test cut-off point and dilution method being used.

One of fifteen male urin diluted up to two hundred showed a positive result. According to Sato, ${ }^{21}$ PSA concentration in male urin is $800 \mathrm{ng} / \mathrm{ml}$. Mathematically, PSA is not detectable in male urin diluted up to $1 / 200$. This positive result may be caused by several factors, including subject urinating shortly after ejaculation, and the collected urin is initial stream urin. Thus, the PSA concentration in urin is higher than normal state.

According to some studies, PSA can be found in female body fluid. Breul ${ }^{23}$ states that PSA concentration in female urin is $3.72 \mathrm{ng} / \mathrm{ml}$ in average. The formation of PSA protein is affected by steroid; therefore, it can be developed in various body tissue including female tissue. ${ }^{16,24}$ Nevertheless, the PSA concentrations in female urin were very low, so it was not detected by PSA rapid test since it is below cut-off point of the device. This study supports the theory, because all of the female urin samples showed negative results. Thus, a false positive result caused by female urin can be eliminated.

The high sensitivity of PSA rapid test (100\%) is suitable for seminal fluid screening test. This device is also able to detect seminal fluid diluted up to one million making the test ideal for forensic use in sexual assault cases, in which the amount of specimens are usually very low.

This device also has a high specificity. The proportion of false positive was $6,67 \%$, due to male urin. Considering that to prove sexual intercourse has occurred, forensic practitioners must find specific components from male origin in female genitalia. So, this false positive shouldn't interfere the certainty of examiners to assure sign of sexual intercourse.

Overall, this device has a very good diagnostic value $(\operatorname{LR}(+)>10$ and LR (-) 0$)$. Therefore, this tool is highly recommended to determine that the specimen examined is seminal fluid without being doubt of urin contamination, especially female urin.

In fact, in the daily forensic medicine practice, seminal fluid is obtained from vaginal swab, vaginal washing, and stains on clothes or objects in crime scene. Laux ${ }^{22}$ have found that the volume of seminal fluid in single vaginal swab is approximately $150 \mu \mathrm{L}$, and in $1 \mathrm{~cm}^{2}$ stains is about $10 \mu \mathrm{L}$. Based on the data from this study, the researchers recommend to make further study in extracting single vaginal swab in $15 \mathrm{ml}$ aquades and
$1 \mathrm{~cm}^{2}$ stains in $1 \mathrm{ml}$ aquades to avoid high dose hook effect, and close to the optimal dilution of 1/5.000. Study about seminal fluid volume in vaginal washing have not been done. Therefore, the researchers suggest to do study on this matter in order to estimate optimal dilution volume in vaginal washing.

The main difficulty faced by researchers was during dilution phase. Researchers realized that this is a limitation of this study. Firstly, seminal fluid serially diluted using conventional pipette, not a micropipette, in which the volume of drops could not be measured, so the possibility of dilution error is very high. Secondly, researcher conducted the dilution alone, so it takes a lot of time to work on one sample. In one day, researcher examines $3-5$ samples. Therefore, the samples could not be examined immediately. This time interval have become a confounding factor which could interfere the result of this study. Researchers recommend to conduct similar studies using time variable to find out whether the reactivity of PSA will be reduced from time to time.

In conclusion, PSA Rapid Test is very specific and sensitive to detect PSA in seminal fluid. Therefore, this device is suggested for forensic use in sexual assault cases.

\section{Acknowledgments}

We would like to thank Mrs. Mildawati and Mrs. Nuliyanah Rachmat Hidayat as representative of $A C O N$ Laboratories, San Diego, $C A$, for donating $A C O N^{\circledR}$ PSA Semi-Quantitative Rapid Test Device to support this study. We also thank The Head of Department of Biology, MAKMAL, and Clinical Laboratory Faculty of Medicine University of Indonesia for picking up our samples that allowed us to conduct this study.

\section{REFERENCES}

1. Brown KP, Sommers MS. Injury and forensic examination of the victim. In: Practical aspects of rape investigation, A multidisciplinary approach. $4^{\text {th }}$ ed. Hazelwood RR, Burgess AW, editors. Boca Raton: CRC Press; 2009.

2. Linden JA, O'Connor AL, Jackson MC. Forensic examination of adult victims and perpetrators of sexual assault. In: Forensic Emergency Medicine. $2^{\text {nd }}$ ed. Olshaker JS, Jackson MC, Smock WS, editors. USA: Lippincott Williams \& Wilkins; 2007.

3. Tjaden P, Thoennes N. Extent, nature and consequences of rape victimization: findings from the national violence against women survey. Washington, DC: US Department of Justice, Office of Justice Programs; 2006.

4. MacDonald R. Time to talk about rape. Br Med J. 2000; 321: 1034-35.

5. Wilken J, Welch J. Management of people who have been raped. Br Med J. 2003; 326: 458-59.

6. United Nations. Seventh United Nations Survey of Crime Trends and Operations of Criminal Justice Systems, 
covering the period 1998 - 2000. [cited 2011 Jan 11]. Available from: URL: http://www.unodc.org/pdf/crime/ seventh_survey/7sc.pdf.

7. Singh SR. Forensic evidence in rape cases in Nepal (Dissertation). Kathmandu School of Law; 2008. [cited 2011 Jan 11]. Available from: URL: www.ksl.edu.np/ cpanel/pics/application_of_forensic_evidence_sunil.pdf.

8. Idries AM. Kejahatan seksual. In: Pedoman ilmu kedokteran forensik. $1^{\text {st }}$ ed. Jakarta: Binarupa Aksara; 1997. [Indonesian].

9. Sampurna B, Samsu Z. Kekerasan terhadap perempuan. In: Peranan ilmu forensik dalam penegakan hukum: Sebuah pengantar. Jakarta; 2003. [Indonesian].

10. Gaensslen RE, Camp FR. Identification of body fluids. In: Sourcebook in forensic serology, immunology, and biochemistry. U.S. Department of Justice: National Institute of Justice; 1983.

11. Kaye S. Identification of seminal stains. Journal of Criminal Law and Criminology of Northwestern University 1947; 38(1): 79-83.

12. Budiyanto A, Sudiono S, Purwadianto A. Pemeriksaan laboratorium. In: Kejahatan seks dan aspek medikolegal gangguan psikoseksual. Jakarta: Kalman Media Pusaka; 1982. [Indonesian].

13. Budiyanto A, Widiatmaka W, Sudiono S, Winardi T, Mun'im A, Sidhi, Hertian S, et al. Pemeriksaan laboratorium forensik sederhana. In: Ilmu kedokteran forensik. $1^{\text {st }} \mathrm{ed}$. Jakarta: Bagian Kedokteran Forensik Fakultas Kedokteran Universitas Indonesia; 1997.

14. Graves HCB, Sensabaugh GF, Blake ET. Postcoital detection of a male-specific semen protein-Application to the investigation of rape . N Engl J Med. 1985; 312: 338-42.

15. DiMaio VJ, DiMaio D. Rape. In: Forensic pathology. $2^{\text {nd }}$ ed. USA: CRC Press; 2001.
16. Rao AR, Motiwala HG, Karim OMA. The discovery of prostate-specific antigen. BJU International; 2007.

17. Laux DL, Custis SE. Forensic detection of semen III. Detection of PSA using membrane based test: Sensitivity issues with regards to the presence of PSA in other body fluids. [cited 2011 Jan 11]. Available from: URL: http:// www.mafs.net/pdf/forensicdetectionsemen3.pdf.

18. Hochmeister MN, Budowle B, Rudin O, Gehrig C, Borer $\mathrm{U}$, et al. Evaluation of Prostate-Specific Antigen (PSA) membrane test assays for the forensic identification of seminal fluid. J Forensic Sci. 1999; 44: 1057-60.

19. Acon PSA. A rapid test for the semi-quantitative detection of prostate specific antigen (PSA) in whole blood, serum, or plasma [package insert]. San Diego: Acon Laboratories, Inc.; 2005.

20. Seratec ${ }^{\circledR}$ PSA Semiquant [pamphlet]. In-vitro diagnostic test for professional forensic use for the detection of seminal fluid by the semi-quantitative determination of PSA (Prostate-Specific Antigen). Germany; 2009.

21. Seratec. PSA in body fluids. [cited 2011 Jan 11]. Available from:URL:http://www.seratec.com/docs/user_instructions/ psa_in_body_fluids.

22. Laux DL, Tambasco AJ, Benzinger EA. Forensic detection of semen II. Comparison of the Abacus Diagnostics OneStep ABAcard p30 Test and the Seratec PSA Semiquant Kit for the determination of the presence of semen in forensic cases. [cited 2011 Jan 11]. Available from: URL: http:// www.mafs.net/pdf/laux2.pdf.

23. Breul J, Pickl U, Hartung R. Prostate-specific antigen in urin. Eur Urol 1994; 26(1): 18-21.

24. Breul J, Pickl U, Schaff J. Extraprostatic production of prostate specific antigen is under hormonal control. J Urol 1997; 157(1): 212-3. 